\title{
Shaping the Modern Discourse on Liberty: French Intellectual Debates from Revolution to Dreyfus
}

\author{
Anna Budzanowska \\ Jagiellonian University, Cracow, Poland \\ abudzanowska@gmail.com
}

\author{
Tomasz Pietrzykowski \\ University of Silesia, Katowice, Poland \\ tomasz.pietrzykowski@us.edu.pl
}

Received 25 August 2018; accepted 13 December 2018; published 30 June 2019.

\begin{abstract}
The age of intellectual debates in France between the Revolution in 1789 and the Dreyfus Affair at the turn of the centuries is one of the key sources that enable the understanding of the modern political culture. It concerns, in particular, the modern concept of liberty that became one of the defining values shaping the European political discourse. Thus, the post-revolutionary France remains an extremely valuable source of inspiration when revisiting the essence of many contemporary debates in political philosophy and public discourse. Most of the ideas and arguments in circulation today echo the debates over the liberty, reason, and society that dominated the intellectual climate of that period in the French political history or, at least, heavily depend on the foundational ideas formulated then and there. Thus, they are worth reconsidering.
\end{abstract}

Keywords: liberty; freedom; revolution; republicanism; conservatism; society.

\section{Introduction}

Even a hundred years after the Great Revolution of 1789, its heritage has been a subject of constant controversies. Over time, they transformed into the debate on the foundations and the future of the republic that has shaped the political culture and national identity of modern France. Moreover, it had implications that reached far beyond the borders of that particular country. To a large extent, it influenced the model of the political scene and the basic ideas of its main sides.

One of the key concepts that played an essential role in the emergence of the conservative and republican political ideologies was individual liberty. It was the first in the revolutionary triad of liberté, égalite, fraternité, and became the defining concept of the RepublicanLiberal ideological camp. Its understanding of liberty implied the respect for an individual 
and the powers of their reason. That combination created mistrust on the part of conservatives, who considered it a fatal danger to the social cohesion and legitimate order. They feared that the primacy of personal freedom must give rise to either anarchy or tyranny, as the unprepared individuals would not be able to carry the burden of responsibility for their own life. Thus, the 'unfortunate gift of liberty' may turn out to be a curse, leading to the collapse of the greatest civilizational achievements.

The age of intellectual debates in France between the Revolution in 1789 and the Dreyfus Affair at the turn of the centuries is one of the key sources that enable the understanding of the modern political culture. It also remains an extremely valuable source of inspiration when revisiting the essence of many contemporary debates in political philosophy and public discourse. Most of the ideas and arguments in circulation today echo the debates over the liberty, reason or the social order that dominated the intellectual climate of that period in the French political history or, at least, heavily depend on the foundational ideas formulated then and there. Thus, they are worth reconsidering.

\section{Liberty-Equality-Fraternity: Freedom as the Constitutive Value of Modern France}

The Great Revolution of 1789 has become a critical factor in shaping the modern public discourse and political life. Most of the key concepts within these discourses stem from debates that had paved the way, accompanied, and followed the turmoil of overthrowing the monarchy, adopting new republican constitutions, falling into the Jacobean terror, and, finally assimilating the heritage of the greatest breakthrough in pre-modern European politics.

The founding fathers of the revolution expected that the values of liberty, equality, and fraternity might become a harmonious triad, determining the social and political life of not only France, but the entire Europe of that time. However, these hopes have not been entertained, since very soon it turned out that:

Les hommes de 1789 avaient cru que la reconstruction de l'Etat sur la volonté du peuple donnait la clé du bonheur social, le jacobinisme de 1793 avait figuré l'apogée de ce volontarisme politique, puisque la dictature révolutionnaire avait cru être en mesure de transformer par son action toute la société civile et de recéer des citoyens verteux à partir d'individus mus par l'ëgoisme, or ce surinvestissement politique caractéristique de toute la vie publique française depuis 1789 fleurit de plus belle en février 1848. [...] Au mythe robespierriste de la dictature de la vertu s'est substituée la croyance à la fraternité républicaine où Marx ne cesse de dénoncer sarcastiquement l'illusion française selon laquelle l'Etat produit la société, alors que c'est l'inverse qui est vrai. (Furet, 1997, p. 235)

Within a short time, liberty has been transformed from the ally of equality into its main rival, and the nature of liberty in the context of other key values of the public life has become one of the most important questions of the practical politics and its philosophical underpinnings. 
The Revolution has given almost immediate rise to the excesses of the new regime that used the instruments of terror to bash all its opponents as well as internal competitors. The wave of self-proclaiming assemblies and tribunals that ignored even basic procedural limitations invoked equality as its main goal and ideal. The revolution has distanced itself from the value of liberty in the name of defending equality and combating its enemies. In practice, freedom was brought down to the lack of formal subjection of the people to a despotic king and the old fashioned feudal power structures. It did not, however, guaranteed any constraints regarding the scope of power exercised over each and every individual by the ruling revolutionary group.

Ten months of the great terror created a very deep and long-lasting divide that came to dominate the $19^{\text {th }}$-century politics far beyond France. One of the basic questions it raised was the achievability of the political ideals of the Enlightenment, which made it possible to abolish old, monarchical power, but it also immediately brought horrible abuses of power, carried out in the name of the noble slogans and wise philosophies with regard to a social and economic liberation.

The critics of the liberal heritage of the Great Revolution emphasised its direct relations with the ideas of Jean Jacques Rousseau (1712-1778). They pointed out that the subjection of an individual to the social collective was an intrinsic and inescapable feature of his concept of the primacy of the "general will". It was argued to be the perfect background for the dictatorial or even totalitarian regimes, which all claimed that they represented the highest will of the people, which — as J. J. Rousseau stated - must not be identified with the will of any actual majority of views or preferences. The idea was swiftly merged with the Sieyes' (1748-1836) theory of representation, making the general will delegable on the smaller, elected group of decision-makers. The Jacobean terror, in turn, demonstrated how easily the idea of general will might become the practice of brutal dictatorship violating basic freedom not to a lesser extent than it had been the case in the realities of the pre-revolutionary, feudal ancien régime (Sonenscher, 2008).

Severe criticism against the legacy of the Great Revolution exposed the problem of tensions between the three basic values invoked by the revolutionary movement. The political practice proved how difficult it was to balance liberty with equality. The Revolution itself spectacularly failed to accomplish such a balance. The post-revolutionary political order that was reconstructed by Napoleon Bonaparte repaired some of the gravest failures of the most turbulent stages of the changes, reflecting the basic Enlightenment ideas and values. However, it also brought new threats to liberty as the foundational value of the political and social order. They involved the centralisation of the state administration, the degradation of the province, and the drastic unbalancing with regard to the educational chances that had been available to people born and living in different places and belonging to different layers of the society. 


\section{The Great Revolution and the Shaping of the $19^{\text {th }}$ Century Political Culture}

In France, the debates about liberty that had been continued for the entire $19^{\text {th }}$ century were now overshadowed by the heritage of the Great Revolution. Its main ideological currents were transformed into two key doctrinal and political conceptions, i.e. the counterrevolutionary conservatism and the progressive republicanism. Interestingly enough, both sides accused one another of politically corrupting that heritage. The conservatives claimed that the Jacobean terror ultimately compromised the ideas behind the revolutionary movement, in particular its implied conception of liberty. On the other hand, the Republicans accused the Bonapartism of pervading revolutionary ideas and turning them into the building blocks of imperial despotism. This is why many $19^{\text {th }}$-century French intellectuals shared the view expressed succinctly by Ernst Renan (1823-1892), according to whom "on the day when France cut off the head of its king, it committed suicide" (Renan, 1871/1875, p. 8).

One of the first and most important critical analyses of the French revolutionary heritage with respect to the concept of liberty was delivered by Benjamin Constant (1767-1830). Following Anne-Louise de Staël (1766-1817), he emphasised that the first stage of the revolution had abolished feudal absolutism and introduced the republican rule of law. It paved the way for the emergence of the modern concept of individual liberty, as opposed to its classic construction as a political society's collective power to self-decide (Fontana, 2016).

According to Constant, however, the later stage of the Jacobean terror led to a deep revision of the revolutionary triad, subjecting liberty to the brutal dominance of utopian equality. Constant claimed that the primacy of egalitarianism had actually deformed the civilisationenhancing influence of the Revolution and seriously compromised its contribution to the political development of France. The unlimited sovereignty of the people had finally prevailed over the individual liberty of a person. Thus:

The axiom of the people's sovereignty has been thought of as a principle of freedom. It is in fact a principle of constitutional guarantee. It aims, in fact, to prevent any individual from seizing the authority which belongs only to the political society as a whole. It determines nothing, however, about the nature of this authority itself. It does not add, in any way, to the sum of individual liberties, therefore, and if we do not turn to other principles for determining the extent of the popular sovereignty freedom could be lost. It may well happen despite the respect for the sovereignty of the people, or even because of it. (Constant, 1806, p. 35)

Constant believed that Jean Jacob Rousseau was to be blamed for providing the intellectual background for that perversion of the revolutionary development. That is why he considered Rousseau's thought as his main ideological target. For Constant:

The mistake of Rousseau and of writers who are the greatest friends of freedom, when they grant society a boundless power, comes from the way their ideas on politics were formed. They have seen in history a small number of men, or even one alone, in possession of immense power, which did a lot of harm. But their wrath has been directed against the wielders of power and not the power itself. Instead of destroying it, they have dreamed only of relocating it. It was a plague, but they took it as something to be conquered; and they endowed 
the whole society with it. Inevitably it moved from there to the majority and from the majority into a few hands. It has done just as much harm as before, and hostility to all political institutions has accumulated in the form of examples, objections, arguments, and evidence. (Constant, 1806, p. 21)

Contrary to this, he maintained that there must be an absolute limit of any political power over an individual, one that would be set up by the principles of justice and natural rights. Without this, any form of government, including a thoroughly democratic one, is bound to degenerate and evolve into tyranny.

For him, Bonapartism was an example of a despotism pretending to protect liberty in order to boost popular support for making all individuals ultimately dependent on the political government. This way, the state became the actual master of every citizen without breaching the principles of the political sovereignty of the people. On the basis of such critique, the author proposed the model of a liberal state that would respect the principles of constitutionalism, individual liberty, and the rule of law. Liberty in its modern meaning is to become achievable only in the post-revolutionary era.

The ideas conceived by Constant were continued by liberal thinkers of the Restoration and July Monarchy periods, namely Pierre-Paul Royer Collard (1763-1845) and François Guizot (1787-1874). They exposed even more dangers brought by the revolutionary turmoil, such as the disintegration of long-lasting traditional communities that broke important social ties. It created a space which could be easily filled by the state ready to govern all aspects of a human life (Berstein, 1999). When the political system is not based on a sufficient respect of liberty of the individual, and the spontaneous creation of social relations and self-governing processes, the temptation to abuse power to dictate all its citizens how to live may be difficult to resist.

Important considerations with regard to the effects of the Great Revolution and its aftermaths for the development and implantation of the idea of liberty were also provided by two eminent liberal historians, i.e. Jules Michelet (1798-1874) and Edgar Quinet (18031875), both of whom authored the classic, in-depth historical analyses of the revolutionary period in France. Both of them argued that despite all the aberrations taking place in the course of the Revolution itself, it ultimately succeeded in implementing the triad of values as the foundation of the French political and social life. In particular, the ideas of liberty and equality became the centrepiece of the post-revolutionary public discourse (Touchard, 1981). The democratic processes that were launched by the outburst of the revolution were also a kind of catharsis for the privileges and institutions stemming from the ancien régime.

Noteworthily, the recognition of the value of the Revolution prevented Michelet from supporting the July Monarchy and made Quinet oppose Napoleon III. The long-term political evolution of France throughout the whole $19^{\text {th }}$ century may be regarded as a huge verification of those beliefs held by the two leading French historians. Democratic principles were challenged by the defenders of the remains of the conservative, feudal, pre-revolutionary social order. The successive republics fell and recovered under the enormous pressure of anti-democratic ideologies and interests. Even bloody episodes, such as the crushing of the 
Commune of Paris, would eventually strengthen the democratic ideas and their political support. The attempts to restore the monarchical political order did not result in the stability that the system had enjoyed in the pre-revolutionary period, and the ideas of liberty and other values brought out by the Revolution effectively prevented the restoration of the social and cultural underpinnings on which the feudal system had once been based.

Irrespective of all this, that period witnessed a long line of intellectual champions that would discuss the concept of liberty as part of the heritage of the greatest social and political breakthrough of the modern Europe, i.e. the Great Revolution of 1789. This group includes, above all, Rene Chateaubriand (1768-1848) with his landmark Essai sur les Révolutions (1797). He believed that, despite all horrors brought by the revolutionary terror, the natural order that would be worthy of the French national character was a republic. Therefore, the monarchy was doomed to collapse. He sympathised with the Rousseau theory, although remained critical of the actual practice and achievements of the revolutionary period.

Counterrevolution was to become a kind of myth, linking post-revolutionary France with its pre-revolutionary past. Because of this, the ideas advocated by Chateaubriand were popular among both sides of the main ideological divide. His thought found the brilliant continuation in the writings of Alexis de Tocqueville (1805-1859), who completed them with the important reflection on political liberty. His inquiries led him to the conclusion that the forming of the post-revolutionary republican order was not free from the dangers to liberty present in the old monarchical despotism (Lacoff, 1987).

This political scientist was preoccupied mainly with the threats to liberty. In respect of that, he was inspired by his well-known travels across North America, which had recently been established based on the 1787 Constitution. He found out that the very foundations of the liberal democracy produced its own perils for the political liberty of an individual. As the author famously observed:

The idea that the right to govern society belongs to the majority because of its enlightenment was carried to the soil of the United States by the first inhabitants. This idea, which alone would be enough to create a free people, has today passed into the mores, and you find it in the least habits of life. The French, under the old monarchy, held as a given that the king could do no wrong; and when he happened to do something wrong, they thought that the fault was with his advisors. This facilitated obedience marvelously. You could murmur against the law, without ceasing to love and respect the law-maker. Americans have the same opinion about the majority. The moral dominion of the majority is based as well on the principle that the interests of the greatest number must be preferred to those of the few. Now, it is easily understood that the respect professed for this right of the greatest number naturally increases or decreases depending on the state of the parties. When a nation is divided among several great irreconcilable interests, the privilege of the majority is often unrecognized, because it becomes too painful to submit to it. [...] The consequences of this state of affairs are harmful and dangerous for the future. (Tocqueville, 1835/1992, pp. 406-407)

Tocqueville's concerns for the future of freedom in a liberal state extended not only to politics, but also aesthetics. His anxiety was shared by several other important thinkers of that time, such as Charles Baudelaire, Gustav Flaubert, or Frederick Nietzsche. They were 
also worried about the imminent civilisational collapse caused by popular democracy and massive consumptionism. In the political philosophy of Tocqueville, a powerful merger between liberalism and conservatism began to shape.

The author considered revolutions as dangers and complained that his lifetime were concurrent with the period of the final stage of the long revolution that destroyed the old state but did not manage to replace it by anything that would be stable enough. He left France in the symbolic moment of Louis Napoleon's coup d'etat when the period of Restoration began. As Zbigniew Rau points out, Tocqueville tried to defend the basic liberal values of personal autonomy, property, freedom of speech or assembly, as well as the independence of the judiciary and the limited power of government. He did it, however, in a conservative way, i.e. through seeking solutions in discipline, self-restraint, the civilising influence of religion and traditional morality, as well as the benefits of living in a community (Rau, 2000, p. 51).

The author considered those virtues the only rescue in the face of the general collapse of the feudal social and political order, and distrusted that the newly designed one would be able to safeguard the very values in the name of which the ancien régime had been overthrown. He did not believe that the values making up the revolutionary triad could be reconciled in any meaningful and politically operative way. He was deeply distrustful to democracy as the order in which public opinion gains the overwhelming influence of views and tastes of any individual.

The price of equality in a democratic society must be the individuality and personal freedom suppressed by the collective power of the society, which no individual is able to resist. The liberty cannot survive without the intermediate level between an individual and the state. It was constituted by the web of voluntary organisations that made citizens able to effectively participate in the public life and represent their views against the rest of the society. This way, an individual might avoid isolation and helplessness in the clash with the predominant influence of the public opinion.

The second condition without which individual liberty cannot be saved, according to Tocqueville, is restraining egoistic inclinations of human beings. Democracy as such fosters such inclinations more than it helps to mitigate them. The author observed that the newly emerged middle class demonstrated greed and unconstrained strive for hedonistic, petty pleasures. In the long run, the philosopher believed, these flaws could be fatal for personal freedom.

Democracy based on people seeking small and common emotions turns to ubiquitous equality. It is available to everyone and does not require any community action, it can be enjoyed in isolation. Man exists only for himself and there is no homeland anymore. There is an authority which wants to satisfy human needs and to watch over the fate of citizens. [...] This authority is absolute, meticulous, pedantic, anticipating and trying to imprison people irrevocably. [...] The democracy gives scarcely what is needed to live honestly to those who govern it, but it spends enormous sums to relieve the needs, or to facilitate the pleasures of the people. In general, democracy gives little to those who govern a great deal to the governed. (Tocqueville, 1835/1992, p. 343) 
People who are utterly concentrated on themselves and their petty pleasures and ordinary business may give up interest in the public life, leaving space for the growing government replacing the traditional forms of a spontaneous cooperation within social groups. This is the way down towards transforming the democracy into a mild and socially accepted despotic order, in which people are satisfied with the care of public affairs provided by the state exercising discreet control over individuals. Thus, democracy, unconstrained individualism, and mundane hedonism may, paradoxically, result in citizens voluntary giving up an ever greater scope of liberty in favour of the growing government relieving them from the burden of taking care of public affairs, making it even easier to enjoy the pleasures dictated by the common tastes.

Constant and Tocqueville belonged to a political tradition that came to an end with the death of the author of Democracy in America. The two major French figures of the second half of the nineteenth century, namely Hippolyte Taine (1828-1893) and Ernest Renan, already belonged to a different school. Tocqueville — and, in many ways, Constant — formed part of the rationalistic and humanistic tradition of the French Enlightenment (Sternhell, 2010, p. 56).

This tradition, however, was confronted by an eminent historian, Hippolyte Taine. He continued and developed the conservative tradition combined with the ideas of the French positivism. Taine believed that in history, as in the natural sciences, there are immutable laws. In his works, he came back to the idea that the French Revolution had not only been a political turmoil, but had actually constituted the clash of two civilisations, i.e. the rationalistic and revolutionary worldview based on the Enlightenment challenged the conservative, Christian ancien régime. As Taine argued:

Two enormous machines, thrust forward with all their weight and full speed, met face to face not by chance but as a fatality. An entire age of literature and philosophy had provided the fuel that carried them and determined the course they were to take - one crusade against another. (Taine, 1864, p. 288)

Based on his inquiries into what he took to be the laws, Taine defied the theories of the revolutionary change, in particular the ideology underpinning the Jacobean camp and its dictatorship, in which he identified the utopian consequences of the rationalist philosophies of the Enlightenment. The historian described the doctrines and ways of thinking of les philosophes and their faithful Jacobean disciples in the following way:

They seem to think, indeed, that human society does not exist, and that they are appointed to create it. Just as well might ambassadors 'of hostile tribes, and of diverse interests, set themselves to arrange their common lot as if nothing had previously existed.' There is no hesitation. They are satisfied that the thing can be easily done, and that, with two or three axioms of political philosophy, the first man that comes may make himself master of it. An immoderate conceit of this kind among men of experience would seem ridiculous; in this assembly of novices, it is a strength. A flock which has lost its way follows those who appears to forge ahead; they are the most irrational but they are the most confident, and in the Chamber, as in the nation it is the daredevils who become leaders. [...] When statesman encounters an abstract principle of sovereignty on his path, he will accept it but imagine its 
operation [...] the Jacobin did the opposite. His principle was the axiom of political geometry, which contained its own evidence. (Taine, 1876, p. 12)

Taine put forward the view that the Revolution and Jacobeans not only had taken over and tried to uncritically and carelessly implement utopian philosophical ideas. Taine quoted the classic texts of the J. J. Rousseau, Second Discourse and Social Contract, that made him the core of the Republican camp and the object of hatred from the supporters of the ancien régime. For Taine, it was the crucial point of the ideological confrontation. As he complained:

The dogma of the sovereignty of the people, interpreted by the masses, was to produce a perfect anarchy until the time that, interpreted by the leaders, it would produce the perfect despotism. [...] The experience of the revolutions in the nineteenth century developed the promising idea that the theory of the sovereignty of the people has two aspects. On the one hand, it can lead to an extreme weakening of the executive - a perpetual demolition of the government - and on the other hand, it brings about a boundless dictatorship of the State. (Taine, 1876, p. 182)

The author's analyses brought him to the theoretical appraisal of the state and its historical roots. The respect for the traditions let the state become the unique instrument to defend the civilisational heritage against destructive revolutionary riots. Being principally pessimistic with respect to the human nature, he believed that the established social order was the only effective tame to chaos and anarchy. Thus, the properly rooted institutions are an indispensable condition for any political liberty. As he put it in one of his major works:

The new popular leader-Philosophy, fallen into such hands, seems to parody itself; and nothing equals its emptiness unless it mischievousness and success. Lawyers, in the sixty assembly districts, roll out the high-sounding dogmas of the revolutionary catechism. This or that one, passing from the question of a party wall to the constitution of empires, becomes the improvised legislator, so much the more inexhaustible and the more applauded as his flow of words, showered upon his hearers, proves to them that every capacity and every right are naturally and legitimately theirs. (Taine, 1876)

For Taine, the ultimate proof of the collapse of the individualistic ideologies of the Enlightenment was the rise and fall of the Paris Commune. It ended the series of attempts to implement utopian ideas into the French political institutions, which had been initiated by the Great Revolution of 1789. On the other hand, the traditional social order is a constraint to the power of administration and the tyranny of the state. The threat from the utopian individualism consists of breaking those basic social ties, thus paving the way for an omnipotent state government crushing the liberty of the people. He emphasised that:

Twenty million French people barely exceeded the mental state of the Middle Ages, which is why in their main outlines the society had to be organized as in the Middle Ages. For this reason, the French were not prepared for the responsible use of freedom and still are not. (Taine, 1880)

This was why the author argued for reinforcing the basic social communities which should be respected by the state and make up the layer of social self-organisation, in which actual human beings might flourish. At the same time, such a layer fills the space that would be 
otherwise immediately taken over by the government. Hence, the traditional social order is, for Taine, not an enemy but an ally of personal liberty. Here, one can touch upon an important aspect of Taine's analysis, namely that the end of the $19^{\text {th }}$ century was to play an essential role in the fight against the principle of the autonomy of the individual and democracy that was derived from it.

The ideas advocated by Taine were fundamental not only on their own merits, but also as an inspiration for more radical conservative French thinkers that continued to emerge until the mid-twentieth century, who rejected the concept and the value of individual freedom as part of what they considered the sinister heritage of the 1789 political upheaval and individualistic, liberal ideologies behind it.

\section{The Forming of the Reactionary and Republican Worldviews}

The emergence of the two opposing camps with radically different perceptions and evaluations of the heritage of the Great Revolution gave rise to the long-lasting model of the political scene, with its main divide between the conservative, pro-religious right, and the progressive, secular left. The shaping of the political discourse around these two main ideological narratives was stimulated by the greatest judicial scandal of modern Europe, namely the trial and conviction of Alfred Dreyfus (Harris, 2010).

The whole affair, from the accusation to rehabilitation of Captain Dreyfus, attracted attention from large parts of the French society for more than a decade. It gave rise to countless debates, polemics, and arguments that helped to consolidate two political worldviews that would remain dominant in the French public life for the next century.

On the one hand, the Dreyfusard part of the society believed mainly in an individual liberty stemming from the liberal ideas behind the Great Revolution. For them, the central question was constraining the government and protecting citizens against the arbitrary power and abuses it may give rise to. This was the ground for the liberal rule of law that was to flourish in Europe as the key constitutional idea at the turn of the centuries.

Furthermore, the Dreyfusards extended the liberty on such achievements of the revolution such as freedom of speech or assembly. The idea of political liberty drew upon the concept of natural rights and freedoms expressed for the first time in La Déclaration des droits de l'homme et du citoyen, adopted in the early stage of the Great Revolution.

The ideas of the anti-Dreyfusard right considered such esprit révolutionnaire as the greatest danger for France and the nation (Maurras, 1937, pp. 148-152). They identified it with the triad of the liberty, equality, and fraternity. In particular, they objected to the interpretation of liberty adopted by the Republican side of the political spectrum. Thus, the conception of liberty and the conditions of its preservation became one of the key differences between the main ideologies that began to shape the French political discourse of that time. 
For anti-Dreyfusards, the value of freedom was related mainly to the collectively understood nation. They accused the elevation of individual and their freedoms of the corruption of the collective spirit underlying the political community. They thought of it as leading to the atomisation of society and protection of every whim of an individual, thus detaching them from the common good. As one of the then leaders of the anti-Dreyfusard camp, Charles Maurras, put it:

The Political freedom destroys respect for the leges naturae. The work and heritage of nature and reason count less than anything. The French state unconscious and careless against natural and spiritual laws exposes itself to the greatest danger-moral decay. (Maurras, 1905, p. 109)

Another famous intellectual champion of the anti-Dreyfusard right was Maurice Barrès. He equated the community with the civilisational and cultural heritage accumulated throughout the century. It creates, as he claimed, the soul of the whole society emerging by the gradual elimination of contingent, individual influences and foreign infiltrations (Barrès, 1897).

According to the author, liberty is actually part of such a collective spirit of the French nation. It belongs both to the legacy of the ancien régime as well as the historical experience of the Great Revolution. It is not, however, a freedom of a rational, isolated individual, but a scope of discretion of a human being as part of their national community. It is made possible only by the social order and institutional arrangements, within which a person may flourish and enjoy some margin of their own decisions. The community is constitutive to the identity of an individual and the very condition of their opportunities with regard to self-governance. In his essay Le culte du moi, Barrès explained that "it is through my ' $I$ ' that I recognized that 'I' individual is completely supported and animated by society" (Barrès, 1888, p. 52).

This is why in the pivotal stage of the Dreyfus affair, Barrès gave unequivocal priority to the good of France (as he understood it) over an individual and their personal rights. However, whenever the latter undermines the prestige of the basic institutions, they must give way to the government protecting the higher good of the whole community.

The conservative ideology combined its conception of an individual and their freedom with the scepticism of the idea of equality, which was the second greatest value of the revolutionary ideology. People from this side of the debate were afraid of its consequences, which they considered to be the shift from the decisive power to the masses of people, who were poorly prepared to take wise individual decisions about the community and the state. Therefore, they reversed the order of interests, claiming that the common good, i.e. the national interest, actually defines the individual goods and interests of the people and the reason of the state. Hence, it is not the case that the common good is a plain sum of the individual preferences and interests of the individuals. To some extent, it is the other way round. As Charles Maurras explained:

La raison d'Etat est dans la nature des choses. Mais tant vaut un Etat sa raison. La raison d'un Etat placé au-dessus des partis s'inspire des nécessités supérieures de l'existences de la nation. Un Etat créé par les partis, ballotté entre les partis, n'a d'autre raison que celle qu'il 
peut avoir: elle est courte, bornée, successive, contradictoire. Elle couvre les intérêts particuliers au lieu de défendre les intérêts généraux. (Maurras, 1937, p. 124)

This caused many eminent intellectuals of the French right to defend the government, even in the face of evidence that it had committed an act of outrageous individual injustice against Captain Dreyfus. It had to be tolerated in the name of the national interest that required the protection of the reputation of the army and the morale of the society in the midst of the very unstable and dangerous international situation.

For a long time, the opponents of this stance, i.e. the Republican camp, were dispersed and heterogeneous. All this made them weak and unable to adequately address the powerful spirit of the age represented by the conservative, anti-Dreyfusard intellectuals. However, the shock that the public opinion experienced when the revelations regarding the governmental conspiracy to cover the actual evidence of Alfred Dreyfus innocence saw the light of the day helped to undermine the moral case of the conservative thinking and its practical consequences.

The Republican side of the society consolidated in particular as a result of the famous and groundbreaking article by Emile Zola, entitled J'accuse...! (Zola, 1898). To a large extent, his achievements and ideas personified the whole basis on which the republic was founded. This is what made his public intervention such a strong and unequivocal alert, spreading awareness about how the basic values were being betrayed through the practices of the French government.

As a consequence, doubts were cast on the soundness of ideas and theories that had led so many prominent thinkers to defend what turned out to be a patently unjustifiable and unscrupulous act of state oppression against an innocent, loyal, and respectable officer of the army. For many French people, it was just a kind of empirical proof of where the noble conservative ideas may lead in practice as well as what positions they are able to place their supporters in. It was a litmus test that conservatism clearly failed. This is why Emile Zola's manifest is regarded as one of the most important defences of individual rights and liberty that has ever been written (Snyder, 1973).

His personal reputation and writing skills unquestionably helped to expose the essence of the debate and the way in which it summarises the ideological struggles of the century. As he pointed out:

Et l'acte que j'accomplis ici n'est qu'un moyen révolutionnaire pour hâter l'explosion de la vérité et de la justice. Je n'ai qu'une passion, celle de la lumière au nom de l'humanité qui a tant souffert et qui a droit au Bonheur. Ma protestation enflammée n'est que le cri de mon âme. Qu'on ose donc me traduire en cour d'assise et que l'enquête ait lieu au grand jour! (Zola, 1898)

Zola's protest made the government charge him with slander, put him on a manipulated trial, find him guilty, and convict him (imprisonment). It triggered the immediate reaction among the Republican-leaning parts of society. They began to organise against what they perceived as the policy of the growing abuses of power violating the basic liberties on which 
the republic was founded. A former minister of justice, Ludovic Trarieux, established a group that came to be known as Human Rights League (LDH) (Main, 1987, pp. 174-182). The ideas they proclaimed as the basic goals and principles to strive for became the backbone of a renovation of the French Republic as well as set the direction that the whole modern Europe later followed. Their core were the liberal ideals of individual freedom and protection against the abuse of power and arbitrary actions of the government. It was based on the respect of reason, human dignity, and equality of citizens, and led to the reorganisation of the state, civil supervision on the military, the secularisation of the state, public discourse as well as civic education.

The doctrines advocated by LDH elicited a series of evetns in a political turmoil that followed, constituting the upheaval in the French political culture and social life. The republican values became the essence of the popular mindset and the foundation of the public discourse shaping the further evolution of political institutions. They were transformed, however, into another triad, i.e. "Citizen, Republic, France", in which they continue to define the political identity of the French people today (Berstein, 1999, p. 11). The conservative distrust against the individual, their rights and liberties was overcome and turned into the ideology of a dissenting minority.

\section{Concluding Remarks}

The $20^{\text {th }}$-century French political culture has been dominated by the Republican mindset shaped in the aftermath of the Dreyfus Affair (Berstein, Rudelle 1992, pp. 147-157). The ideas promoted by the counter-revolutionary movement had been transformed into a conservative, pro-religious side of the French political spectrum, which was then seriously impaired by the positions taken by the main thinkers with regard to the accusation and imprisonment of an innocent officer of the French military.

Over time, most of the warnings and predictions that motivated the conservative attitudes of the $19^{\text {th }}$-century French right were proven false or exaggerated. Most of what seemed inevitable to Tocqueville has not materialised. The threats of an excessive individualism, unlimited liberty of isolated, solitary human beings have turned out largely unsubstantiated. Not only has the society based on liberal, individualistic principles not disintegrated, but it also paved the way to the unparalleled thrive of human welfare and civilisational progress.

The real danger to the human spirit came with the $20^{\text {th }}$-century return of the mythology of the primacy of collective entities, i.e. a nation with its blood or a class with its historical destiny. Nonetheless, it has been successfully overcome by the ideas of individual freedom, republicanism, and human dignity. That let the humanity achieve the unprecedented success in terms of the most objective, statistical data. It could happen because of the spirit of the Enlightenment and its emphasis on reason, respect for an individual human being, their liberty, rights, and dignity (Pinker, 2018). 
The intellectual and political history of Europe has been shaped mainly through the $19^{\text {th }}$ century struggles over the heritage of the Great French Revolution. In the course of that struggle, the liberal political ideology had to overcome the resistance of the main enemies of the modern conception of freedom. One of them was the ultra-revolutionary idea of the utopian equality taking precedence over respect for individual liberty underpinning the excesses of the Jacobean dictatorship. The other one was the conservative counter-revolutionary spirit striving to reverse the direction of cultural evolution and restore the old order based on the deeply anti-individualistic foundations. However, nothing could make us believe today that either of these enemies has been ultimately defeated and ceased to be dangerous for the future of liberty. One of the important lessons from the history of ideas is that the same dangers might emerge in different disguises.

\section{References}

Barrès, M. (1888). Le cult du moi. Paris, France: Edition Poche.

Barrès, M. (1897). Le roman de l'énergie national: Les Déracines. Paris, France: BibliothèqueCharpentier.

Berstein, S. (1999). Les cultures politiques en France. Paris, France: Seuil.

Berstein, S., \& Rudelle, O. (1992). Le modèle républicain. Paris, France: PUF.

Chateaubriand, F.-R. (1797). Essai sur les Révolutions. Paris, France: Gallimanrd.

Constant, B. (1806). Principles of Politics: Applicable to All Governments, Indianapolis, IN: Liberty Fund.

Fontana, B. (2016). Germaine de Staël: A political portrait. Princeton, NJ: Princeton University Press.

Furet, F. (1997). La Révolution. Paris, France: Hachette.

Harris, R. (2010). Dreyfus: Politics, Emotion and the Scandal of the Century. New York, NY: Metropolitan Books.

Lacoff, S. (1987). Liberty, Equality, Democracy, Tocqueville's response to Rousseau. In G. Feaver, F. Rosen (Eds.), Lives, liberties and the public good (pp. 101-120). London, UK: Palgrave Macmillan.

Main, B. (1987). La Ligue des Droits de l'Homme: Un combat dans le siècle. L'homme et la société, 1987(85-86), 174-182.

Maurras, Ch. (1905). L'Avenir de l'intelligence. Paris, France: Fontemoign.

Maurras, Ch. (1937). Mes idées politiques. Paris, France: Fayard.

Pinker, S. (2018). Enlightenment Now: The case for reason, science, humanism and progress. New York, NY: Viking. 
Rau, Z. (2000). Liberalizm: Zarys mysli politycznej w XIX i XX wieku. Warszawa, Poland: Fundacja Aletheia.

Renan, E. (1875). La réforme intellectuelle et morale de la France. Paris, France: Michel-Levy Frères. (Original work published 1871)

Snyder, L. (1973). The Dreyfus case: A documentary history. New Brunswik, NJ : Rutgers University Press.

Sonenscher, M. (2008). Sans-Culottes: An Eighteenth-Century Emblem in the French Revolution, Princeton, NJ: Princeton University Press.

Sternhell, Z. (2010). The Anti-Enlightenment Tradition, New Haven, CT : Yale University Press.

Staël, A.-L. (1818). Considérations sur la Révolution française, Paris, France: Persee.

Taine, H. (1864). Histoire de la litterature anglaise (Vol. 3). Paris, France: Hachette.

Taine, H. (1875-1893). Les origins de la France contemporaine (édition 11, t. I. L'ancien régime, II à VI La Révolution; V à VI Le Régime moderne). Paris, France: Bouqins. Retreived from : https://www.gutenberg.org/files.html

Tocqueville, A. (1992). De la démocratie en Amérique. Paris, France: Gallimard. (Original work published 1835)

Tocqueville, A. (1953). Ancien régime et la Révolution. Paris, France: Gallimard. (Original work published 1856)

Touchard, J. (1981). Histoire des ideés politiques: 2-du XVIII siècle à nos jours (8 édition). Paris, France: Presses Universitaires de France.

Zola, E. (1898, January 13). J'accuse...!. L'Aurore. 